\title{
Shangwua (Compositae), a new genus from the Qinghai-Tibetan Plateau and Himalayas
}

\author{
Yu-Jin Wang, ${ }^{1,2 *}$ Eckhard von Raab-Straube, ${ }^{3 *}$ Alfonso Susanna ${ }^{4 *} \&$ Jian-Quan Liu ${ }^{1}$ \\ 1 State Key Laboratory of Grassland Agro-Ecosystem, School of Life Science, Lanzhou University, Lanzhou 730000, \\ Gansu, China \\ 2 State Key Laboratory of Systematic and Evolutionary Botany, Institute of Botany, the Chinese Academy of Sciences, \\ Beijing 100093, China \\ 3 Botanischer Garten und Botanisches Museum Berlin-Dahlem, Freie Universität Berlin, Königin-Luise-Str. 6-8, \\ 14195 Berlin, Germany \\ 4 Botanic Institute of Barcelona (IBB-CSIC-ICUB), Pg. del Migdia s.n., 08038 Barcelona, Spain \\ * contributed equally to this work \\ Author for correspondence: Jian-Quan Liu,liujq@nwipb.ac.cn
}

\begin{abstract}
A new genus of Compositae, Shangwua, is described to accomodate all species formerly placed in Saussurea sect. Jacea. This genus is distinct from the other genera of tribe Cardueae in its unique combination of states of characters including involucral bracts, receptacle, paleae, anther, style, achene and pappus. Phylogenetic analyses based on molecular data suggest that this new genus belongs to the Xeranthemum group, a lineage of the Carduinae that diversified early, with only distant relationships to Saussurea and related genera. The genus Shangwua consists of three species occurring in the Qinghai-Tibetan Plateau and Himalayas.
\end{abstract}

Keywords Compositae; Himalayas; molecular phylogenetics; new genus; taxonomic revision; Saussurea; Shangwua

Supplementary Material The Electronic Supplement (Appendix S1: Taxonomic revision under the genus Shangwua; Figs. S1-S5) and the alignment files are available in the Supplementary Data section of the online version of this article (http://www.ingentaconnect.com/content/iapt/tax).

Received: 8 Apr. 2013; revision received: 25 July 2013; accepted: 30 Aug. 2013. DOI: http://dx.doi.org/10.12705/625.19

\section{INTRODUCTION}

Cardueae was one of the first tribes to be recognised in Compositae (Cassini, 1819). Its members share a thickened hairy node below the style branches, and they occur mainly in temperate regions of Eurasia (Dittrich, 1977; Häffner, 2000). The most recent revisions of the tribe (Susanna \& Garcia-Jacas, 2007, 2009) recognised around 2500 species in 73 genera. Four of the genera (Centaurea L., Cirsium Mill., Cousinia Cass., Saussurea DC.) are extremely species-rich (Bremer, 1994; Susanna \& Garcia-Jacas, 2007, 2009). Substantial progress towards understanding the evolutionary relationships of the tribe has been made recently using molecular data (e.g., RaabStraube, 2003; Kita \& al., 2004; Martins, 2006; Susanna \& al., 2006; Barres \& al., 2013). However, generic delimitations and phylogenetic relationships remain unresolved for some groups, notably the Carduus-Cirsium group and, in particular, the Saussurea group.

First established by Candolle (1810a, b), Saussurea was initially described as having a pappus composed of an outer row of short, discrete and scabrid bristles, and an inner layer of long, basally connate and plumose bristles. Candolle later found that certain species assigned to Saussurea lacked an outer row of pappus bristles, although they resembled Saussurea in other characters. He thus established a new genus, Aplotaxis DC., to accommodate these species (Candolle, 1833). However, an outer row of pappus bristles was observed for some Aplotaxis species by Schultz (1846), having merely been overlooked by Candolle. Schultz therefore returned Aplotaxis to synonymy with Saussurea, and this treatment was followed by Clarke (1876), Hooker (1881) and many others. This broad generic circumscription was also adopted by Lipschitz (1979) in his monographic revision of Saussurea, which recognised a total of 390 species and established an infrageneric system of six subgenera and twenty sections. Subsequent floristic works largely followed this system (Chen, 1985; Liu, 1996, 2004; Shi \& Jin, 1999; Saklani \& Rao, 2000), and recently described species have been assigned to these subgenera and sections (Wang \& al., 2005; Fujikawa \& Ohba, 2007; Raab-Straube, 2009, 2011; Liu \& Ho, 2010; Chen, 2010, 2011; Chen \& Gan, 2011). However, the status of Saussurea subg. Jurinocera (Baill.) Lipsch. and S. subg. Frolovia (DC.) Lipsch., and that of S. sect. Elatae Hook. f. within S. subg. Saussurea is controversial, with some authors suggesting that each be recognised as an independent genus based on morphological and molecular phylogenetic evidence (Kamelin, 1993; Häffner, 2000; Raab-Straube, 2003; Kita $\&$ al., 2004; Shi \& Raab-Straube, 2011). Others have suggested transferring these three groups into the genera Jurinea Cass. 
or Dolomiaea DC. (Susanna \& al., 2006; Wang \& al., 2007). In the latest taxonomic treatment for China (Shi \& Raab-Straube, 2011), Saussurea sect. Elatae, S. sect. Frolovia (DC.) Kitam. and $S$. sect. Aucklandia (Falc.) O. Hoffm. were treated under the genera Himalaiella Raab-Straube, Frolovia (DC.) Lipsch. and Aucklandia Falc., respectively. The number of remaining Saussurea subgenera and sections in China was reduced to four and eight respectively, including Saussurea sect. Jacea Lipsch., and 289 species of Saussurea were recognised (Shi \& Raab-Straube, 2011).

Previous molecular analyses (Raab-Straube, 2003; Wang $\&$ al., 2009), examined 56 Saussurea species, covering four subgenera and seven of the sections recognised by Shi \& RaabStraube (2011), or all six subgenera and 19 out of 20 sections recognised by Lipschitz (1979). Those analyses confirmed the exclusion of some sections from Saussurea and resulted in the recognition of Saussurea s.str. as a monophyletic lineage (Wang \& al., 2009). In particular, Saussurea forrestii Diels (= Saussurea denticulata (DC.) Wall. ex C.B. Clarke 1876, non Ledeb. 1829, nom. illeg.), up to now placed in Saussurea (subg. Saussurea) sect. Jacea, was found to occupy a relatively basal position in Cardueae, making it only distantly related to Saussurea and its segregates (Wang \& al., 2009). However, the exact systematic position of this species remained uncertain because of the limited number of Cardueae genera sampled in that study. This rather surprising result prompted closer examination of the morphology of the six species (Saussurea fastuosa (Decne.) Sch. Bip., S. forrestii Diels, S. glabrata (DC.) C. Shih, S. jacea (Klotzsch) C.B. Clarke, S. masarica Lipsky, S. tadshikorum Iljin \& Gontsch.) of $S$. sect. Jacea. These species share the following characteristic features: dark-rimmed involucral bracts, elongated receptacular paleae, and a uniseriate or subuniseriate pappus with plumose bristles (Lipschitz, 1979; Shi \& Jin, 1999). These species were diagnosed mainly by the shape and the indumentum of the leaves and some other quantitative characters with continuous variations, which caused delimitations of some species to be extremely difficult (Lipschitz, 1979; Liu, 2004).

Here we present the results of molecular phylogenetic and morphological analyses of these species, designed to determine their true position within tribe Cardueae. Based on these data, a new genus is erected and a taxonomic revision of the group is presented (for the complete taxonomic treatment, see Electr. Suppl.: Appendix S1).

\section{MATERIALS AND METHODS}

Plant material and sampling. - Only two species of Saussurea sect. Jacea were included for molecular phylogenetic study. The examined material of these two species comprised one accession of Saussurea jacea C.B. Clarke from the western Himalayas, and eight accessions of $S$. forrestii from the central Himalayas and the Qinghai-Tibetan Plateau (Appendix 1). The third species (S. masarica) with a distinct morphology was not analyzed because it is difficult to collect fresh material of this species in the field and we also failed to amplify the DNA fragments used in this study from the poor DNAs extracted from the specimens kept in herbaria. For the morphological comparison of the species of the new genus with Saussurea and with possibly related genera identified in previous phylogenetic analyses (Wang \& al., 2009; Barres \& al., 2013; Amphoricarpos Vis., Berardia Vill., Chardinia Desf., Siebera J. Gay, Staehelina L., Xeranthemum L.), selected herbarium specimens were examined (Appendix 2). Additional morphological data were taken from the literature (Bremer, 1994; Dittrich, 1996; Susanna \& Garcia-Jacas, 2007; Shi \& Raab-Straube, 2011). According to our previous and initial phylogenetic examination of all genera of Cardueae (Susanna \& Garcia-Jacas, 2007; Wang \& al., 2009; Shi \& Raab-Straube, 2011; Barres \& al., 2013), the selected genera should comprise all those potentially related to Saussurea sect. Jacea based on both morphological and molecular evidence.

DNA amplification. - Total DNA was extracted from Saussurea forrestii and S. jacea samples using Qiagen DNeasy Kits, following the manufacturer's instructions. Five DNA fragments $(r b c L, n d h F, \operatorname{mat} K, t r n L-F$, ITS) were amplified and sequenced, following the protocol used in our previous studies (Wang \& al., 2009; Zhang \& al., 2009). All five fragments from $S$. forrestii were successfully sequenced, but only the ITS, $\operatorname{trn} L-F$ and partial matK fragments were obtained from $S$. jacea. These fragments, also obtained from five selected species of Saussurea and other related genera, were amplified and sequenced. After validation by visual inspection of chromatograms employing Mega v.4.0 (Tamura \& al., 2007) and further confirmation of the nuclear ITS sequences by forward and backward sequencing, a total of 23 newly obtained sequences were deposited in GenBank (Appendix 1). In addition, sequences representing all known lineages of Cardueae, mainly following Barres \& al. (2013) (Appendix 1), were downloaded.

Phylogenetic analyses. - Two datasets were constructed. The first dataset was composed of nuclear ITS and $\operatorname{trn} L-F$ and matK sequences of Saussurea forrestii, S. jacea and 24 species representing all major subtribes of Cardueae to test whether the two species of Saussurea sect. Jacea form a monophyletic clade and to determine their probable positions in the tribe (Susanna \& al., 2006). The second dataset comprised data from nuclear ITS and trnL-F, matK, $n d h F$ and $r b c L$ for a total of 105 taxa of Carduae (based on Barres \& al., 2013) including $S$. forrestii, in order to further determine the systematic position of $S$. sect. Jacea. Oldenburgia Less. was used as outgroup for the phylogenetic analyses of the first dataset, and additionally Brachylaena R. Br. and Tarchonanthus L. from other tribes of subfamily Carduoideae (Barres \& al., 2013) for the second dataset. The incongruence length difference (ILD) test (Farris \& al., 1995) was used to detect potential conflicts between different DNA fragments, using the partition homogeneity test implemented in PAUP* v.4.0b10 (Swofford, 2003), with 1000 replicates, and the heuristic search option, with 100 random taxon addition and TBR branch swapping.

Mega v.4.0 (Tamura \& al., 2007) was used to calculate genetic distances under the Kimura two-parameter (K2P) model, and to count singleton sites of Saussurea forrestii and S. jacea. Bayesian inference (BI) methods were used to do phylogenetic analyses for all datasets using MrBayes v.2.1 (Ronquist 
\& Huelsenbeck, 2001). The GTR + G model, for which the parameters were initially considered to be unknown and estimated during the course of the run, was employed for the following analyses. Four chains, each with a different starting seed, were run for two million generations, and the temperature was set to the default value of 0.2 . The trees were sampled every 100 generations, and Tracer v.1.5 (http://tree.bio.ed.ac.uk/software/ tracer/) was used to choose a suitable burn-in. Finally, PAUP* v.4.0b10 (Swofford, 2003) was used to calculate a consensus tree and posterior probabilities (PP) from the sampled trees after the burn-in period were then calculated.

\section{口 RESULTS}

Phylogenetic analyses. - Among the eight individuals examined of Saussurea forrestii, no variation was detected for any of the chloroplast loci, but up to four polymorphic sites were detected in their ITS sequences. Since these eight individuals formed a monophyletic lineage, only one sequence was chosen for further analyses. The ILD test revealed the absence of strong conflicts between the chloroplast and nuclear partitions included in the first dataset $(P=0.213)$. From a total of $1604 \mathrm{bp}$, following alignment, 200 singleton and 255 parsimony-informative sites were recovered when the gaps were treated as missing data. The genetic distance between $S$. forrestii and $S$. jacea was found to be $1.98 \%$, far less than the distances between them and the other Saussurea species (4.93\%-5.43\%) or between any other pair of genera (3.33\%-8.18\%). Saussurea forrestii and $S$. jacea formed a highly supported monophyletic clade when the first dataset was examined ( $\mathrm{PP}=100 \%$; Electr. Suppl.: Fig. S1). This clade was only distantly related to the other three selected Saussurea species, and fell outside of a clade comprising these and related genera from in and around the Qinghai-Tibetan Plateau, such as Dolomiaea and Himalaiella.

The ILD test also revealed the absence of strong conflicts between cpDNA fragments included in the second dataset. The aligned fragments comprised a total of $4728 \mathrm{bp}$, with 601 parsimony-informative sites when gaps were treated as missing data. Phylogenetic analysis of this dataset placed Saussurea in a derived position within a strongly supported ( $\mathrm{PP}=100 \%$; Fig. 1) subclade comprising most species of Carduinae but not $S$. forrestii. Instead, $S$. forrestii was revealed to be sister to the Xeranthemum group (Amphoricarpos, Chardinia, Siebera and Xeranthemum; $\mathrm{PP}=100 \%$; Fig. 1), which is one of the basal lineages of Carduinae.

Morphological differences. - All species of Saussurea sect. Jacea share certain characters with other Saussurea species. They all have multiple rows of imbricate involucral bracts, discoid, homogamous capitula and a plumose, basally connate pappus (Lipschitz, 1979; Bremer, 1994; Susanna \& Garcia-Jacas, 2007; Shi \& Raab-Straube, 2011). However, they show marked differences to Saussurea in a number of characters, as described below (Figs. 2, 3, 4A-L) and in Table 1.

The roots of $S$. sect. Jacea are lignified, and field observations suggest that this species is capable of clonal reproduction
(Figs. 2B, 3F). Both these features have rarely been reported for other Saussurea species (Lipschitz, 1979; Shi \& Raab-Straube, 2011). The receptacle is alveolate and almost flat (Fig. 4D, J), whereas in most Saussurea species the margin of the alveolae is elongated, forming many subulate, acute bristles. Conversely, in the remaining Saussurea sections true paleae are lacking, whereas in $S$. sect. Jacea, 1-2 cm long paleae (one per floret) are present. Involucral bracts in $S$. sect. Jacea have dark, lacerate and membranous margins (Figs. 2C, 3E, 4A, G). Anther tails of $S$. sect. Jacea species are short and undivided (Figs. $2 \mathrm{H}, 4 \mathrm{C}, \mathrm{I}$ ), while those of most remaining Saussurea species are deeply lacerate or woolly. Both genera have thickened hairy nodes below the style branches, but in $S$. sect. Jacea (Figs. 2I, J, 4B, H) these are at least three times longer than those of the remaining Saussurea species and other genera of Cardueae examined. The character of short and acute style branches is shared between $S$. sect. Jacea (Figs. 2I, 4B, H), genera of subtribe Carlininae, and the Xeranthemum group of Carduinae (Susanna \& Garcia-Jacas, 2007). Style branches of most Saussurea species, however, are linear, apically obtuse to sub-obtuse, and at least twice as long as broad (Lipschitz, 1979; Bremer, 1994; Shi \& Raab-Straube, 2011). The pappus of $S$. sect. Jacea is homomorphic, consisting of a single row of connate, plumose pappus bristles that form a basal ring (Fig. 4E, F, K, L). It therefore lacks the outer layer of distinct, scabrous pappus bristles that are diagnostic for Saussurea. In this respect, $S$. sect. Jacea resembles Carlina L. (Susanna $\&$ Garcia-Jacas, 2007). Occasionally, some of these bristles are shorter and bent outwards, so they can easily be mistaken for a second row of bristles. However, Saussurea species always have an inner row of plumose bristles that are connate at the base, and nearly always an outer row of scabrid bristles, which are free from each other, deciduous and much shorter than the inner ones. In contrast to the other Saussurea species, the pappus of $S$. sect. Jacea is directly and firmly attached to the pericarp wall and not surrounded by an apical rim (Fig. 4F, L). This character is also common in the Carlininae, in Berardia and Staehelina, and in the Xeranthemum group (Dittrich, 1996; Susanna \& Garcia Jacas, 2007).

Saussurea sect. Jacea differs from Berardia, Staehelina and the Xeranthemum group in having a pappus of plumose bristles instead of smooth to scabrid or barbellate bristles or scarious scales (Table 1). The paleae (one per floret) are coriaceous, subulate, apically bent or hooked, and always longer than the florets (Fig. 4D, J), whereas the paleae or bristles in the other genera are scarious, straight and usually shorter than the florets. Saussurea sect. Jacea is also unique among the basal genera of Cardueae in having coriaceous or herbaceous involucral bracts with a broad, scarious, blackish and often lacerate margin (Fig. 4A, G). Involucral bracts in the Xeranthemum group, for example, are scarious and often coloured. Saussurea sect. Jacea has homogamous capitula and achenes that are glabrous and smooth (Fig. 4E, K), whereas all other genera of the Xeranthemum group have heterogamous capitula and achenes that are sericeous and often sulcate. It also differs from these in its perennial habit; the genera Chardinia, Siebera and Xeranthemum are all annual. 


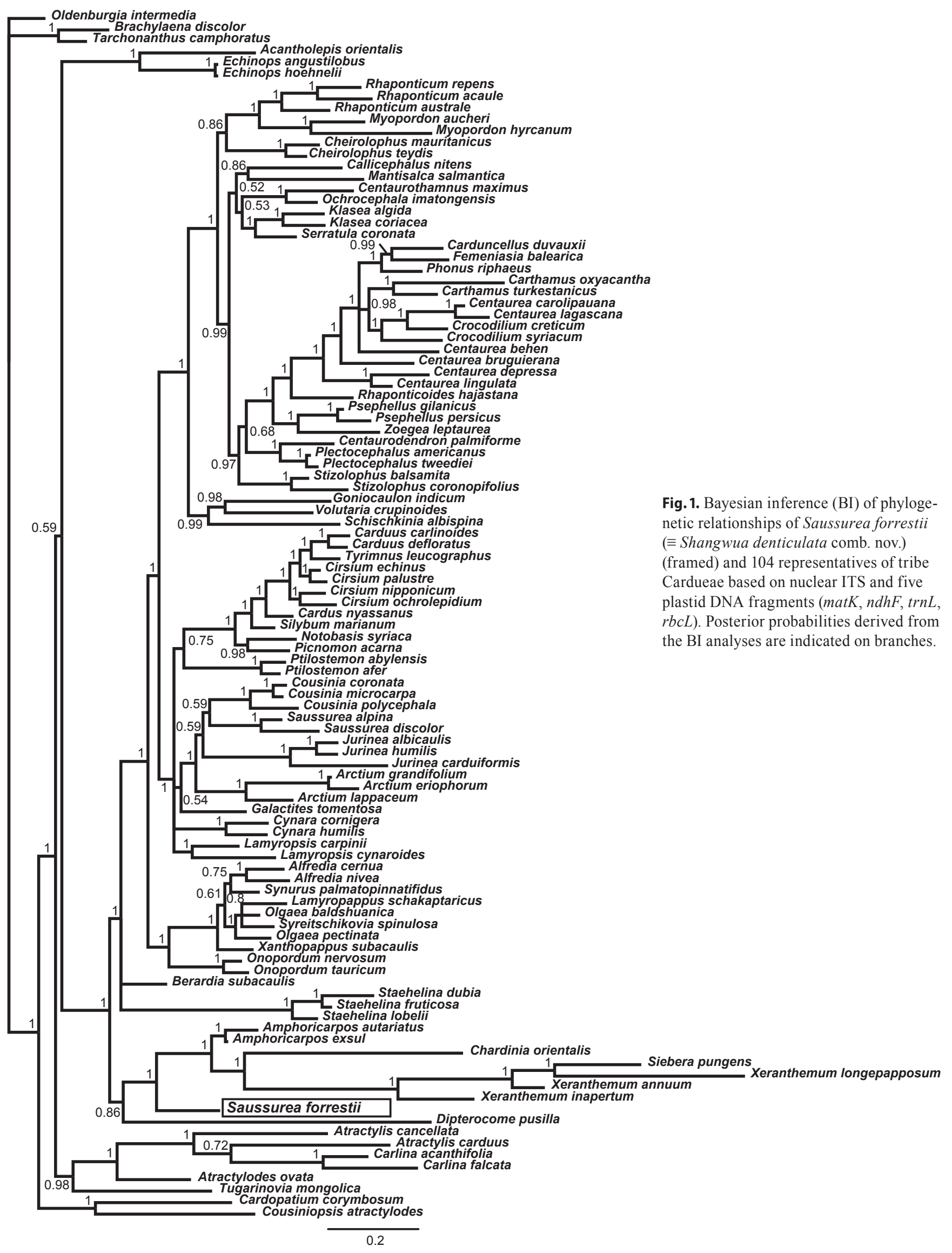




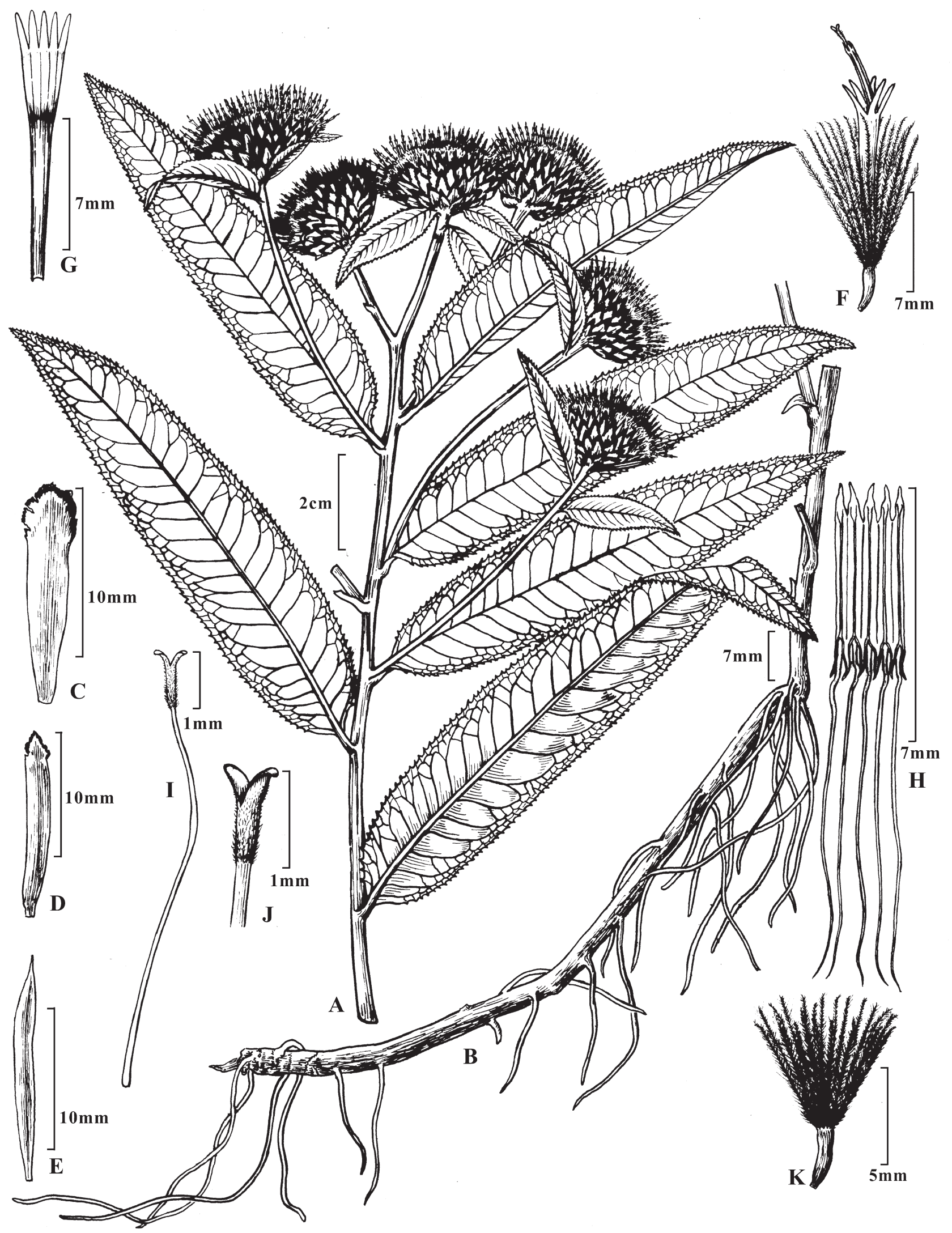

Fig. 2. Shangwua denticulata comb. nov. (from J.Q. Liu 07150, LZU). A, habit; B, rootstock; C-E, involucral bracts from outer to inner row; F, floret; G, corolla; H, stamens; I, style; J, upper part of style with short branches and thickened hairy node; K, achene with pappus. — Drawn by Han-Ping Yu. 


\section{DISCUSSION}

The pappus structure is the main diagnostic character used to delimit Saussurea (Candolle, 1810a, b, 1833; Schultz, 1846; Lipschitz, 1979; Shi \& Raab-Straube, 2011). Himalaiella and Frolovia both comprise species that were previously included in Saussurea (Raab-Straube, 2003) but differ in having only one homomorphic row of pappus bristles, rather than the two heteromorphic rows found in most Saussurea species. While the status of these segregates is still a matter of debate, they are unambiguously only distantly related to Saussurea, and closer to Jurinea (Susanna \& al., 2006). In S. sect. Jacea, the pappus also consists of a single row of basally connate, plumose bristles. Some of these bristles can be markedly shorter than the others and more strongly bent outwards, resembling an outer row. Moreover, the pappus of $S$. sect. Jacea is inserted on top of the achene, a character shared with Carlininae and the Xeranthemum group; in other members of Carduinae including Saussurea, Himalaiella and Frolovia, the pappus is surrounded by the apical rim of the achene (Häffner, 2000).

Our molecular phylogenetic analyses suggest that the two species of $S$. sect. Jacea examined (S. forrestii, $S$. jacea) are closely related to each other, comprising a monophyletic clade among the genera of Cardueae (Electr. Suppl.: Fig. S1). However, this clade is not closely related to Saussurea, nor to any of the genera closely allied to it (Fig. 1). Instead, our phylogenetic analyses confirm that $S$. sect. Jacea occupies a rather isolated position within the Xeranthemum group, a lineage of subtribe Carduinae that apparently diversified early. The reconstructed phylogenetic relationships, together with its unique combination of morphological characters, strongly support the recognition of $S$. sect. Jacea as a new genus.
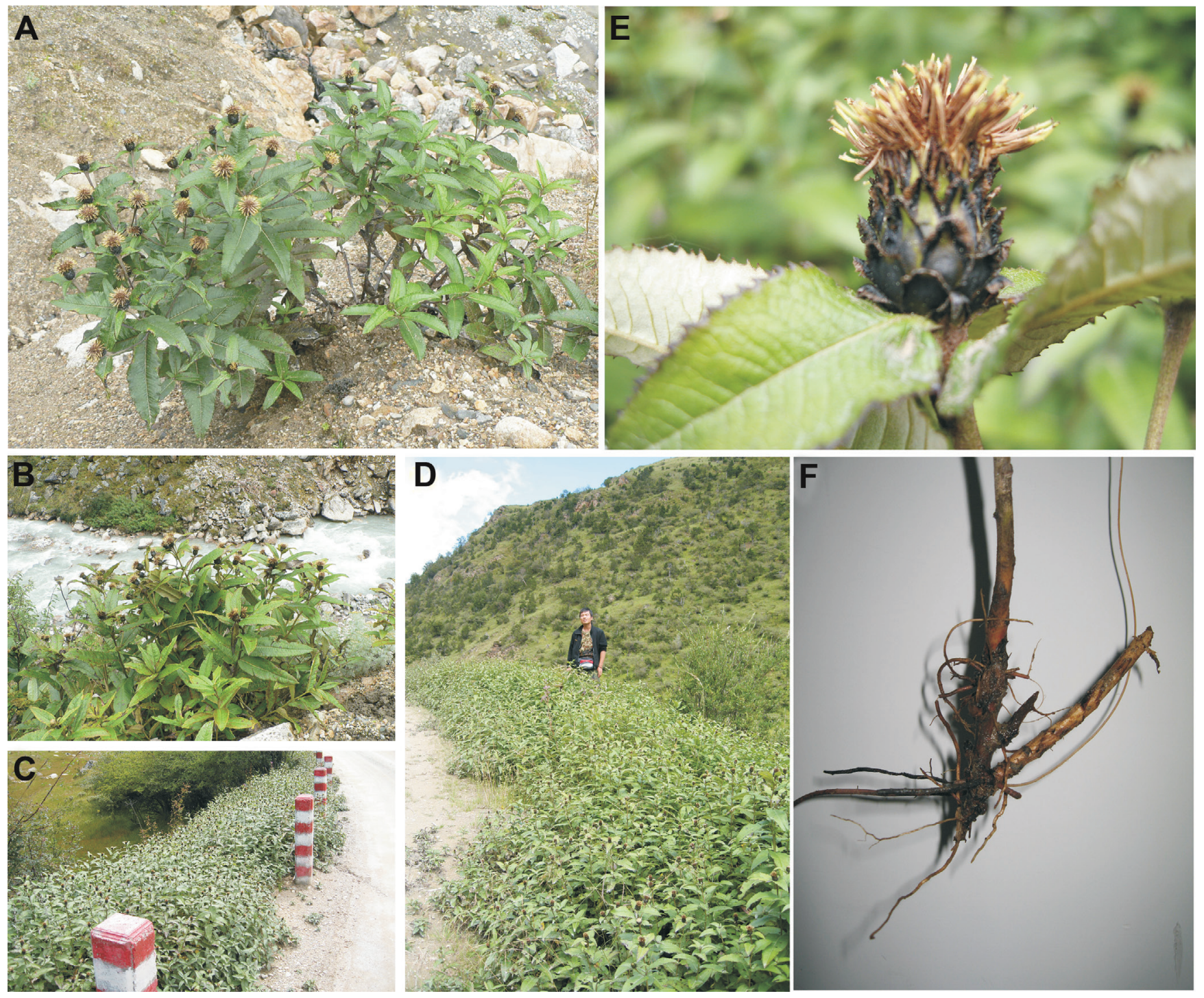

Fig. 3. Photographs of Shangwua denticulata comb. nov. A, habit; B-D, habitat; E, capitulum with subtending leaves; F, rootstock with adventive shoots. - A-B, China, Xizang, Jilong (J.Q. Liu Liujq-09xz-lzt-073, LZU); C-F, China, Xizang, Nielamu (J.Q. Liu 07150, LZU). 

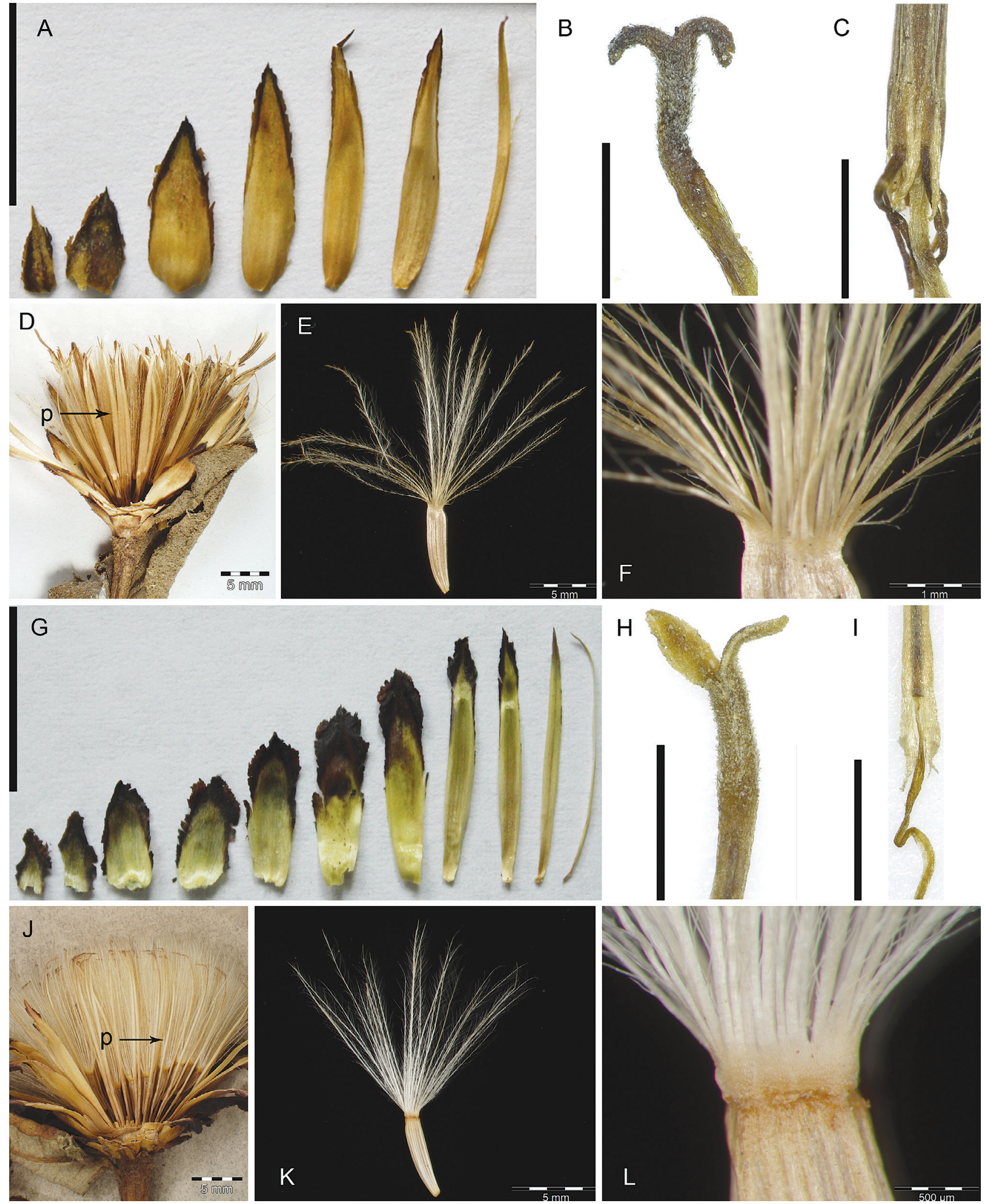

Fig. 4. Morphological details of two species of Shangwua gen. nov. A-F, Sh. jacea (A-C from D.J. Broadhead 119, E; D-F from Koelz 2617, L0833898); G-L, Sh. denticulata (G-I from J.Q. Liu 07150, LZU; J-L from Dhewoj 256, E00451529). A, G, involucral bracts (from outer to inner rows); B, H, style branches; C, I, anther tails; D, J, fruiting capitulum with involucral bracts partly removed, receptacle with paleae (p); E, K, achene with pappus; F, L, insertion of pappus on achene. - Scale bars: A, G = 1 cm; B, C, F, H, I = $1 \mathrm{~mm}$; D, E, J, K = 5 mm; L=0.5 mm. 
Our morphological examinations show that all species of $S$. sect. Jacea share a number of distinctive morphological characters such as involucral bracts, receptacular paleae, shape of anther tails, style branches, achenes and pappus structure and insertion. This combination of characters clearly distinguishes the new genus from both Saussurea and all other genera of Cardueae (Table 1). However, these characters provide no clear clues to the relationship of this new genus to other basal genera of subtribe Carduinae, e.g., Xeranthemum, Staehelina and Berardia. In some respects, species of the new genus are

Table 1. Diagnostic features of Shangwua (三Saussurea sect. Jacea), Saussurea (the remaining sections) and basal genera of tribe Cardueae.

\begin{tabular}{|c|c|c|c|c|c|c|c|c|}
\hline Character & Shangwua & Saussurea & Berardia & Staehelina & Amphoricarpos & Xeranthemum & Siebera & Chardinia \\
\hline Life form & $\begin{array}{l}\text { perennial } \\
\text { herbs or } \\
\text { subshrubs }\end{array}$ & $\begin{array}{l}\text { biennial or } \\
\text { perennial } \\
\text { herbs, rarely } \\
\text { subshrubs }\end{array}$ & $\begin{array}{l}\text { perennial } \\
\text { rosulate } \\
\text { herbs }\end{array}$ & $\begin{array}{l}\text { shrubs or } \\
\text { subshrubs }\end{array}$ & $\begin{array}{l}\text { perennial } \\
\text { herbs or } \\
\text { subshrubs }\end{array}$ & annual herbs & annual herbs & annual herbs \\
\hline Capitula & $\begin{array}{l}\text { homoga- } \\
\text { mous }\end{array}$ & $\begin{array}{l}\text { homoga- } \\
\text { mous }\end{array}$ & $\begin{array}{l}\text { homoga- } \\
\text { mous }\end{array}$ & $\begin{array}{l}\text { homoga- } \\
\text { mous }\end{array}$ & $\begin{array}{l}\text { heteroga- } \\
\text { mous (outer } \\
\text { florets } \\
\text { female) }\end{array}$ & $\begin{array}{l}\text { heteroga- } \\
\text { mous (outer } \\
\text { florets } \\
\text { sterile) }\end{array}$ & $\begin{array}{l}\text { heteroga- } \\
\text { mous (outer } \\
\text { florets } \\
\text { sterile) }\end{array}$ & $\begin{array}{l}\text { heterogamous } \\
\text { (outer florets } \\
\text { female) }\end{array}$ \\
\hline $\begin{array}{l}\text { Involucral } \\
\text { bracts }\end{array}$ & $\begin{array}{l}\text { ovate with } \\
\text { scarious, } \\
\text { lacerate dark } \\
\text { rim }\end{array}$ & $\begin{array}{l}\text { variable, } \\
\text { but without } \\
\text { lacerate dark } \\
\text { rim }\end{array}$ & $\begin{array}{l}\text { subulate, } \\
\text { woolly }\end{array}$ & $\begin{array}{l}\text { ovate- } \\
\text { lanceolate, } \\
\text { without } \\
\text { lacerate dark } \\
\text { rim }\end{array}$ & $\begin{array}{l}\text { scarious, } \\
\text { ovate- } \\
\text { lanceolate to } \\
\text { obovate and } \\
\text { mucronate }\end{array}$ & $\begin{array}{l}\text { scarious, } \\
\text { inner ones } \\
\text { elongate and } \\
\text { coloured }\end{array}$ & $\begin{array}{l}\text { scarious, } \\
\text { inner ones } \\
\text { coloured and } \\
\text { pungent }\end{array}$ & $\begin{array}{l}\text { scarious, } \\
\text { obovate to } \\
\text { lanceolate }\end{array}$ \\
\hline Receptacle & $\begin{array}{l}\text { with } 1.3-1.5 \\
\text { cm long, } \\
\text { subulate, } \\
\text { apically } \\
\text { hooked pa- } \\
\text { leae, longer } \\
\text { than florets }\end{array}$ & $\begin{array}{l}\text { mostly with } \\
\text { numerous } \\
\text { alveolate } \\
\text { subulate } \\
\text { bristles, } \\
\text { shorter than } \\
\text { florets, or } \\
\text { alveolate }\end{array}$ & $\begin{array}{l}\text { alveolate, } \\
\text { without } \\
\text { bristles }\end{array}$ & $\begin{array}{l}\text { with scari- } \\
\text { ous, silvery } \\
\text { subulate } \\
\text { scales, } \\
\text { shorter than } \\
\text { florets }\end{array}$ & $\begin{array}{l}\text { with scari- } \\
\text { ous, apically } \\
\text { lacerate sil- } \\
\text { very scales, } \\
\text { shorter than } \\
\text { florets }\end{array}$ & $\begin{array}{l}\text { with scari- } \\
\text { ous, linear- } \\
\text { lanceolate } \\
\text { scales, } \\
\text { longer than } \\
\text { florets }\end{array}$ & $\begin{array}{l}\text { with scarious } \\
\text { scales }\end{array}$ & $\begin{array}{l}\text { with scarious, } \\
\text { lanceolate } \\
\text { to subulate } \\
\text { scales }\end{array}$ \\
\hline Anther tails & $\begin{array}{l}\text { short, undi- } \\
\text { vided }\end{array}$ & $\begin{array}{l}\text { mostly } \\
\text { woolly or } \\
\text { strongly } \\
\text { lacerate }\end{array}$ & $\begin{array}{l}\text { short, lacini- } \\
\text { ate to entire }\end{array}$ & $\begin{array}{l}\text { strongly } \\
\text { lacerate }\end{array}$ & $\begin{array}{l}\text { short, lacini- } \\
\text { ate to entire }\end{array}$ & $\begin{array}{l}\text { short, lacini- } \\
\text { ate to entire }\end{array}$ & $\begin{array}{l}\text { short, lacini- } \\
\text { ate to entire }\end{array}$ & $\begin{array}{l}\text { short, lacini- } \\
\text { ate to entire }\end{array}$ \\
\hline $\begin{array}{l}\text { Style } \\
\text { branches }\end{array}$ & $\begin{array}{l}\text { short, diver- } \\
\text { gent, apex } \\
\text { acute }\end{array}$ & $\begin{array}{l}\text { long, } \\
\text { strongly } \\
\text { divergent, } \\
\text { apex obtuse }\end{array}$ & $\begin{array}{l}\text { short, coher- } \\
\text { ent, apex } \\
\text { obtuse }\end{array}$ & $\begin{array}{l}\text { very short, } \\
\text { coherent, } \\
\text { apex obtuse }\end{array}$ & $\begin{array}{l}\text { short, diver- } \\
\text { gent, apex } \\
\text { acute }\end{array}$ & $\begin{array}{l}\text { very short, } \\
\text { divergent, } \\
\text { apex obtuse }\end{array}$ & $\begin{array}{l}\text { very short, } \\
\text { coherent, } \\
\text { apex obtuse }\end{array}$ & $\begin{array}{l}\text { very short, } \\
\text { divergent, } \\
\text { apex obtuse }\end{array}$ \\
\hline Achenes & $\begin{array}{l}\text { glabrous, } \\
\text { without } \\
\text { coronula }\end{array}$ & $\begin{array}{l}\text { mostly } \\
\text { glabrous, } \\
\text { with distinct } \\
\text { apical rim or } \\
\text { crown }\end{array}$ & $\begin{array}{l}\text { glabrous, } \\
\text { slightly } \\
\text { sulcate }\end{array}$ & $\begin{array}{l}\text { glabrous or } \\
\text { sericeous, } \\
\text { with a min- } \\
\text { ute coronula }\end{array}$ & sericeous & sericeous & $\begin{array}{l}\text { sericeous, } \\
\text { sulcate }\end{array}$ & $\begin{array}{l}\text { dimorphic, } \\
\text { glabrous or } \\
\text { partly seri- } \\
\text { ceous }\end{array}$ \\
\hline $\begin{array}{l}\text { Pappus } \\
\text { structure }\end{array}$ & $\begin{array}{l}\text { homomor- } \\
\text { phic, uniseri- } \\
\text { ate, plumose } \\
\text { bristles }\end{array}$ & $\begin{array}{l}\text { heteromor- } \\
\text { phic, biseri- } \\
\text { ate bristles; } \\
\text { outer ones } \\
\text { mostly sca- } \\
\text { brid, inner } \\
\text { ones longer } \\
\text { and always } \\
\text { plumose }\end{array}$ & $\begin{array}{l}\text { homo- } \\
\text { morphic, } \\
\text { multiseriate } \\
\text { bristles, ba- } \\
\text { sally smooth, } \\
\text { apically } \\
\text { scabrid }\end{array}$ & $\begin{array}{l}\text { homomor- } \\
\text { phic, uniseri- } \\
\text { ate bristles, } \\
\text { basally } \\
\text { smooth, api- } \\
\text { cally scabrid }\end{array}$ & $\begin{array}{l}\text { homomor- } \\
\text { phic, uniseri- } \\
\text { ate bristles, } \\
\text { basally } \\
\text { smooth, api- } \\
\text { cally scabrid }\end{array}$ & $\begin{array}{l}\text { homomor- } \\
\text { phic, uniseri- } \\
\text { ate, scarious } \\
\text { scales, ba- } \\
\text { sally smooth, } \\
\text { apically } \\
\text { scabrid }\end{array}$ & $\begin{array}{l}\text { homomor- } \\
\text { phic, uniseri- } \\
\text { ate, scarious } \\
\text { scales, ba- } \\
\text { sally smooth, } \\
\text { apically } \\
\text { scabrid }\end{array}$ & $\begin{array}{l}\text { homomor- } \\
\text { phic, uniseri- } \\
\text { ate, scarious } \\
\text { scales, ba- } \\
\text { sally smooth, } \\
\text { apically } \\
\text { scabrid }\end{array}$ \\
\hline $\begin{array}{l}\text { Pappus } \\
\text { insertion }\end{array}$ & $\begin{array}{l}\text { directly } \\
\text { attached on } \\
\text { upper edge } \\
\text { of achene }\end{array}$ & $\begin{array}{l}\text { attached } \\
\text { within api- } \\
\text { cal rim of } \\
\text { achene }\end{array}$ & $\begin{array}{l}\text { directly } \\
\text { attached on } \\
\text { upper edge } \\
\text { of achene }\end{array}$ & $\begin{array}{l}\text { directly } \\
\text { attached on } \\
\text { upper edge } \\
\text { of achene }\end{array}$ & $\begin{array}{l}\text { directly } \\
\text { attached on } \\
\text { upper edge } \\
\text { of achene }\end{array}$ & $\begin{array}{l}\text { directly } \\
\text { attached on } \\
\text { upper edge } \\
\text { of achene }\end{array}$ & $\begin{array}{l}\text { directly } \\
\text { attached on } \\
\text { upper edge } \\
\text { of achene }\end{array}$ & $\begin{array}{l}\text { directly } \\
\text { attached on } \\
\text { upper edge of } \\
\text { achene }\end{array}$ \\
\hline
\end{tabular}


morphologically intermediate between the Xeranthemum group and subtribe Carlininae, especially in terms of pappus characters (Dittrich, 1996).

Saussurea sect. Jacea currently comprises three morphologically recognisable and geographically separate species in the western and central Himalayas and the Qinghai-Tibetan Plateau, indicating that it diversified within this region. Two of its species were first described under Aplotaxis (or Haplotaxis, a mere orthographic variant). However, the name Aplotaxis is typified by a species that belongs to Saussurea (Raab-Straube, 2003), so it cannot be used for this genus (Art. 10.2, Melbourne Code, McNeill \& al., 2012). Therefore, the new genus name Shangwua is proposed here, to accommodate the accepted species formerly placed in Saussurea sect. Jacea.

\section{TAXONOMIC TREATMENT}

Shangwua Yu J. Wang, Raab-Straube, Susanna \& J. Quan Liu, gen. nov. $\equiv$ Saussurea sect. Jacea Lipsch. in Bot. Mater. Gerb. Bot. Inst. Komarova Akad. Nauk S.S.S.R. 16: 441. 1954 - Type: Shangwua jacea (Klotzsch) Yu J. Wang \& Raab-Straube.

Description. - Perennial herbs with woody rootstock. Stems solitary, erect, usually much-branched, densely leafy. Leaves alternate, shortly petiolate or sessile, undivided, largest at middle of stem, the lower and upper ones smaller, glabrous or abaxially densely tomentose and with sessile glands. Capitula numerous or few, usually solitary and terminal on stem and branches, homogamous, discoid. Involucral bracts in several rows, imbricate, leathery, straw-coloured with brown or black membranous margin. Receptacle flat, alveolate, without numerous alveolar bristles, but paleate with one palea per floret; paleae 1.2-2 cm, usually longer than inner phyllaries. Florets all fertile, hermaphroditic. Corolla tubular, glabrous, actinomorphic, limb \pm as long as tube, throat 2-3 times longer than lobes. Filaments glabrous. Anther tube with short, undivided basal appendages. Style with thickened, 1.5-2 mm long hairy node below branches; style branches flat, acute or subacute, very short (less than $1 \mathrm{~mm}$ ), diverging. Achenes glabrous, cylindrical, longitudinally ribbed, with basal attachment scar; apex truncate, without conspicuous rim. Pappus homomorphic, bristles straw-coloured to brownish, arranged in a single row, plumose, unequal in length, connate at base and fused with achene, persistent.

Etymology. - The name Shangwua is proposed here after the given name of Prof. Shangwu Liu, a taxonomist who has made major contributions to our understanding of the Compositae of the Qinghai-Tibetan Plateau.

Taxonomy and distribution. - After a complete revision, three species are recognised under the genus Shangwua (see below; for details see Electr. Suppl.: Appendix S1). All of them are distributed in high mountains of Asia. Two of them occur in Pamir, Hindukush and Karakorum, whereas the third has a wider distribution on the southern edge of the Qinghai-Tibetan Plateau from the western Himalaya in India to the Hengduan mountains in Yunnan and Sichuan (Fig. 5).

\section{Key to three species recognised in Shangwua}

1. Middle stem leaves lanceolate, more than $6 \mathrm{~cm}$ long, margin serrulate or denticulate ... 1. Shangwua denticulata

1. Middle stem leaves ovate to elliptic, less than $6 \mathrm{~cm}$ long, margin entire or minutely denticulate ............... 2

2. Middle stem leaves ovate or elliptic, more than $2 \mathrm{~cm}$ wide, abaxially usually green, glabrous, but densely glandular, margin entire ...................... 2. Shangwua jacea

2. Middle stem leaves ovate, less than $2 \mathrm{~cm}$ wide, abaxially usually whitish, densely arachnoid-tomentose, margin minutely denticulate

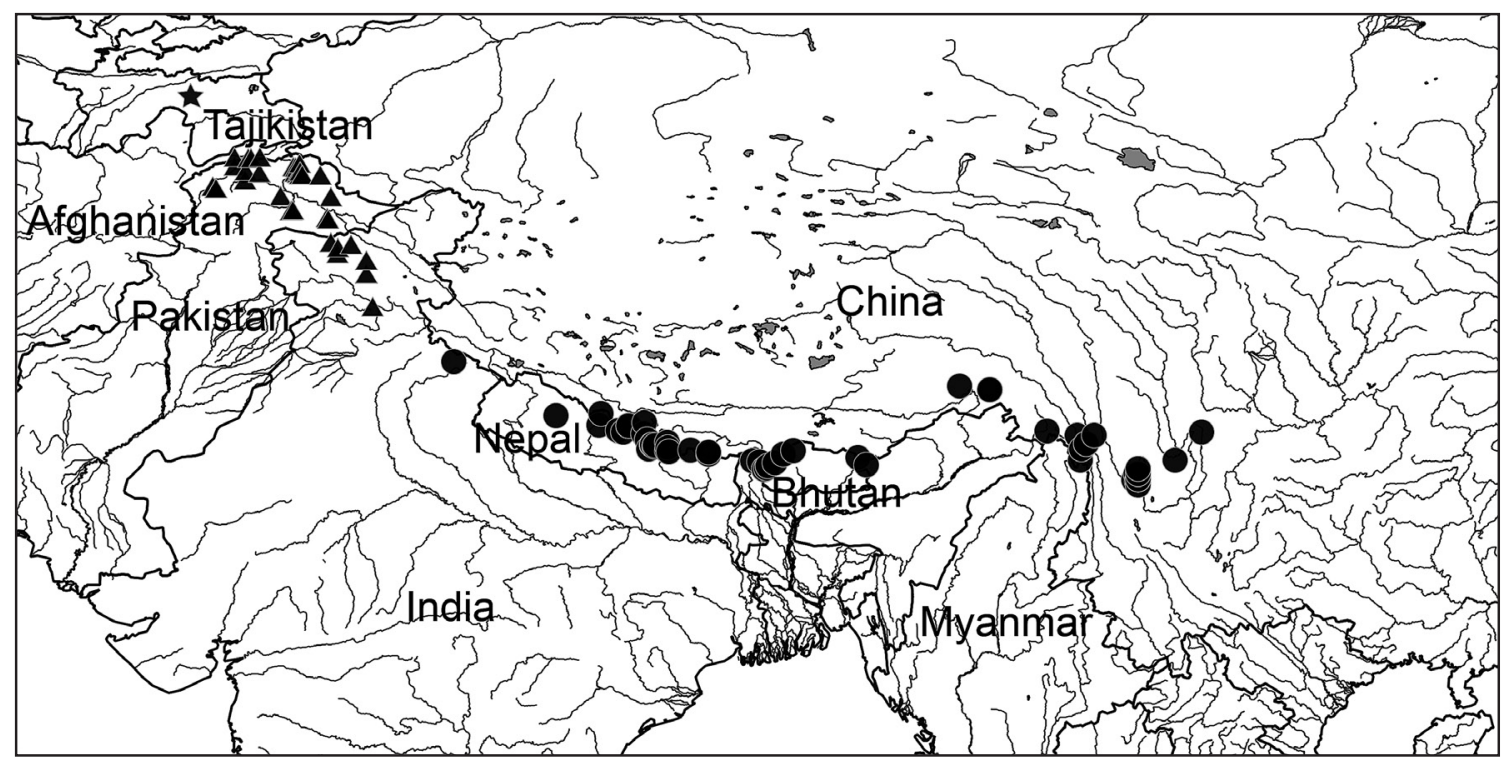

Fig. 5. Distribution of Shangwua masarica (star), Sh. jacea (triangles) and Sh. denticulata (circles). 
1. Shangwua denticulata (DC.) Raab-Straube \& Yu J. Wang, comb. nov. $\equiv$ Aplotaxis denticulata DC., Prodr. 6: 539. $1838 \equiv$ Aplotaxis denticulata var. glabrata DC., Prodr. 6: 540. $1838 \equiv$ Saussurea wallichii Sch. Bip. in Linnaea 19: 330. $1846 \equiv S$. denticulata (DC.) Wall. ex C.B. Clarke, Compos. Ind.: 234. 1876, non Ledeb. $1829 \equiv$ S. glabrata (DC.) C. Shih in Chen \& Shi, Fl. Reipubl. Popularis Sin. 78(2): 84. 1999 - Lectotype (designated here) of Aplotaxis denticulata and holotype of Aplotaxis denticulata var. glabrata: "27, Saussurea (Serratula) denticulata Wall., Kamaon [= Kumaon], R. Blinkw., Comp. angl. des Indes 1830", Blinkworth s.n. in herb. Wallich 2917/27 (G-DC No. G00137866!; isolectotype: K-W No. 2917!). — Figures 2, 3, 4G-L; Electr. Suppl.: Fig. S2.

= Saussurea forrestii Diels in Notes Roy. Bot. Gard. Edinburgh 5: 198. 1912 - Holotype: "China, NW Yunnan, in pine forest on the eastern flank of the Lichiang range, 10000-11000 ft.", Sep. 1906, G. Forrest 2940 (E No. E00383921!).

Lectotypification. - When Candolle described Aplotaxis denticulata, he recognized two varieties in the material collected by Robert Blinkworth in Kumaon and distributed by Nathaniel Wallich under the herbarium number 2917/C27. The two sheets in the herbarium of Candolle's Prodromus correspond to those two varieties: var. glabrata and var. hypoleuca (Electr. Suppl.: Figs. S2, S3). The specimen which morphologically clearly corresponds to the former variety has a more complete label with indications of collector and locality (Electr. Suppl.: Fig. S2), and is thus chosen as the lectotype for Aplotaxis denticulata $\equiv$ Shangwua denticulata.

\section{Key to varieties of Shangwua denticulata}

1. Leaves abaxially light green, tomentose to glabrescent; veins clearly visible

1a. Shangwua denticulata var. denticulata

1. Leaves abaxially whitish, densely tomentose; veins obscured by indumentum

1b. Shangwua denticulata var. hypoleuca

1a. Shangwua denticulata (DC.) Raab-Straube \& Yu J. Wang var. denticulata.

1b. Shangwua denticulata var. hypoleuca (DC.) Raab-Straube \& Yu J. Wang, comb. nov. $\equiv$ Aplotaxis denticulata var. hypoleuca DC., Prodr. 6: 540. 1838 - Holotype: "C 27, Saussurea denticulata", Blinkworth s.n. in herb. Wallich 2917/27 (G-DC No. G00137917!). — Electr. Suppl.: Fig. S3.

= Aplotaxis fastuosa Decne. in Jacquemont, Voy. Inde 4: 97. 1844 三 Saussurea fastuosa (Decne.) Sch. Bip. in Linnaea 19: 331. 1846 - Holotype: [INDIA]. "Buspa valley", Jacquemont 1150 (P No. P00603697!).

2. Shangwua jacea (Klotzsch) Yu J. Wang \& Raab-Straube, comb. nov. $\equiv$ Aplotaxis jacea Klotzsch in Klotzsch \& Garcke, Bot. Ergebn. Reise Waldemar: 79. 1862 ("Haplo- taxis") $\equiv$ Saussurea jacea (Klotzsch) Clarke, Compos. Ind.: 233. 1876 - Type: "Himalaya, Dr. Hoffmeister" (B, amissus est). Lectotype (designated here): Illustration in Klotzsch \& Garcke, Bot. Ergebn. Reise Waldemar: t. 79. 1862. - Figure 4A-F; Electr. Suppl.: Fig. S4.

= Saussurea jacea var. tomentosa Lipsch. in Novosti Sist. Vyssh. Rast. 1964: 328. 1964 - Holotype: "Kashmir, distr. Baltistan, Drás valley, 10-11000 ft.”, 22 Aug 1893, J.F. Duthie 13701 (LE; isotype: E No. E00451552!).

= Codonocephalum serratuloides Gilli in Oesterr. Bot. Z. 104: 311. 1957 Inula serratuloides (Gilli) Grierson in Notes Roy. Bot. Gard. Edinburgh 33: 250. 1974 - Holotype: [PAKISTAN, GILGIT-BALTISTAN]. Karakorum, between Gasherbrum and Shigar; between Bardumal and Askole", 3500 m, 3 Aug 1956, G. Weiler (W!).

Lectotypification. - The original type specimen collected by W. Hoffmeister was almost certainly housed in the herbarium of Klotzsch (Berlin), which was almost entirely destroyed during the Second World War. The only extant original material is the plate from the protologue (Klotzsch \& Garcke, 1862: t. 79), designated as the lectotype (Fig. S4). It shows some important diagnostic features of the genus in detail, such as the undivided, short, basal anther tails (Fig. 4C), the short, diverging style arms and the long, thickened, hairy zone below the bifurcation (Fig. 4B), the uniseriate pappus (Fig. 4E, F), and a dissected receptacle with few, long paleae (Fig. 4D) instead of the many bristles characteristic of most Cardueae.

3. Shangwua masarica (Lipsky) Yu J. Wang \& Raab-Straube, comb. nov. $\equiv$ Saussurea masarica Lipsky in Trudy Imp. S.-Peterburgsk. Bot. Sada 18: 81. 1900 - Lectotype (designated by Lipschitz, 1979: 103): [TAJIKISTAN]. "Bukhara, Darvaz, Mazarskij khrebet, lednik Badgut, 9000'”, 21 Jul 1899, V.I. Lipsky 286 (LE!). — Electr. Suppl.: Fig. S5.

= Saussurea tadshikorum Iljin \& Gontsch. in Izvest. Tadzhik. Baz. Akad. Nauk SSSR, Bot. 1(1): 67. 1933, syn. nov. - Holotype: "Tajikistan, Wakhshki khrebet", 13 July 1932, N. Gontsharov, G. Grigoriev \& V. Nikitin 639 (LE!).

\section{ACKNOWLEDGEMENTS}

We thank Professors S.W. Liu, R.I. Milne and H. Ikeda for constructively commenting on and editing this manuscript. The genus name Shangwua was used to acknowledge the great contributions to taxonomic knowledge of Compositate in the Qinghai-Tibetan Plateau by Prof. Shangwu Liu in the past 50 years. We are also grateful to Dr. X.M. Tian for generously helping with field investigation. This work was supported by the Natural Science Foundation of China (81274024, 30800064), the Open Funds of State Key Laboratory of Systematic and Evolutionary Botany, Institute of Botany, the Chinese Academy of Sciences (lzusm-wyj), the Ministry of Science and Technology of China (2007FY110100, 2010DFB63500), Fundamental Research Funds for the Central University (lzujbky-2010-54), and the Ministry of Economy and Competitiveness of Spain (CGL2009-13322-C03-03/ BOS). 


\section{口 LITERATURE CITED}

Anderberg, A., Ghahremaninejad, F. \& Källersjö, M. 2007. The enigmatic genus Dipterocome. Compositae Newslett. 45: 2323 2336.

Barres, L., Sanmartín, I., Anderson, C.L., Susanna, A., Buerki, S., Galbany-Casals, M. \& Vilatersana, R. 2013. Reconstructing the evolution and biogeographic history of tribe Cardueae (Compositae). Amer. J. Bot. 100: 867-882. http://dx.doi.org/10.3732/ajb.1200058

Bremer, K. 1994. Asteraceae: Cladistics and classification. Portland: Timber Press.

Candolle, A.P. de 1810a. Observations sur les plantes Composées ou Syngenèses. Premier mémoire. Sur les Composées et les Cinarocéphales en général. Ann. Mus. Hist. Nat. 16: 135-158.

Candolle, A.P. de 1810b. Observations sur les plantes Composées ou Syngenèses. Second mémoire. Monographies de quelques genres de Cinarocéphales. Ann. Mus. Hist. Nat. 16: 181-208.

Candolle, A.P. de 1833. Genres nouveaux appartenant à la famille des Composées ou Synanthérées. Arch. Bot. (Paris) 2: 330-384.

Cassini, H. 1819. Sixième mémoire sur la famille des Synanthérées, contenant les caractères des tribus. J. Phys. Chim. Hist. Nat. Arts 88: 150-163, 189-204.

Chen, Y.L. 1985. Saussurea DC. Pp. 865-914 in: Wu, C.Y. (ed.), Flora Xizangica. Beijing: Science Press.

Chen, Y.S. 2010. Saussurea baoxingensis sp. nov. (Compositae, Cardueae) from Sichuan, China. Nordic J. Bot. 28: 761-763. http://dx.doi.org/10.1111/j.1756-1051.2010.00938.x

Chen, Y.S. 2011. Saussurea megacephala (Asteraceae), a new species from Xizang, China. Ann. Bot. Fenn. 48: 142-144. http://dx.doi.org/10.1111/j.1759-6831.2011.00121_1.x

Chen, Y.S. \& Gan, Q.L. 2011. New species and nomenclatural action in Saussurea DC. (Asteraceae). J. Syst. Evol. 49: 160-161.

Clarke, C.B. 1876. Compositae indicae. Calcutta: Thacker, Spink \& Co.

Dittrich, M. 1977. Cynareae - systematic review. Pp. 999-1015 in: Heywood, V.H., Harborne, J.B. \& Turner, B.L. (eds.), The biology and chemistry of the Compositae, vol. 2. London: Academic Press.

Dittrich, M. 1996. Die Bedeutung morphologischer und anatomischer Achänen-Merkmale für die Systematik der Tribus Echinopeae Cass. und Carlineae Cass. Boissiera 51: 9-102.

Farris, J.S., Källersjö, M., Kluge, A.G. \& Bult, C. 1995. Testing significance of incongruence. Cladistics 10: 315-319. http://dx.doi.org/10.1111/j.1096-0031.1994.tb00181.x

Fujikawa, K. \& Ohba, H. 2007. A new species of Saussurea DC. (Asteraceae) from the Nepal Himalaya. J. Jap. Bot. 82: 328-332.

Häffner, E. 2000. On the phylogeny of the subtribe Carduinae (Cardueae, Compositae). Englera 21: 1-208.

Hidalgo, O., Garcia-Jacas, N., Garnatje, T. \& Susanna, A. 2006. Phylogeny of Rhaponticum (Asteraceae, Cardueae-Centaureinae) and related genera inferred from nuclear and chloroplast DNA sequence data: Taxonomic and biogeographic implications. Ann. Bot. (Oxford) 97: 705-714. http://dx.doi.org/10.1093/aob/mcl029

Hooker, J.D. 1881. Compositae. Pp. 219-415 in: Hooker, J.D. (ed.), Flora of British India, vol. 3. Ashford: Reeve.

Jansen, R.K., Cai, Z., Raubeson, L.A., Daniell, H., Depamphilis, C.W., Leebens-Mack, J., Mueller, K.F., Guisinger-Bellian, M., Haberle, R.C., Hansen, A.K., Chumley, T.W., Lee, S.B., Peery, R., McNeal, J.R., Kuehl, J.V. \& Boore, J.L. 2007. Analysis of 81 genes from 64 plastid genomes resolves relationships in angiosperms and identifies genome-scale evolutionary patterns. Proc. Natl. Acad. Sci. U.S.A. 104: 19369-19374. http://dx.doi.org/10.1073/pnas.0709121104

Kamelin, R.V. 1993. Rod Lipschitziella R. Kam. gen. nov. Pp. 371, 632 in: Vvedenskij, A.I. (ed.), Opreditel' rastenij srednej azii. Kritičeskij konspekt flory. Conspectus florae asiae mediae, vol. 10. Tashkent: Izdatel'stvo "FAN" Uzbekskoj SSR.

Kita, Y., Fujikawa, K., Ito, M., Ohba, H. \& Kato, M. 2004. Molecular phylogenetic analyses and systematics of the genus Saussurea and related genera (Asteraceae, Cardueae). Taxon 53: 679-690. http://dx.doi.org/10.2307/4135443

Klotzsch, J.F. \& Garcke, C.A.F. 1862. Die botanischen Ergebnisse der Reise seiner königl. Hoheit des Prinzen Waldemar von Preussen in den Jahren 1845 und 1846. Berlin: R. Decker.

Lipschitz, S.J. 1979. Rod Saussurea DC. (Asteraceae). Leningrad: "Nauka", Leningradskoje Otdelenie.

Liu, S.W. 1996. Flora Qinghaiica, vol. 3. Xining: Qinghai People's Publishing House.

Liu, S.W. 2004. Saussurea DC. Pp. 518-579 in: Wu, Z.Y. (ed.), Flora Yunnanica, vol. 13. Beijing: Science Press.

Liu, S.W. \& Ho, T.N. 2010. Two new species of Saussurea (Asteraceae) from the Qinghai-Xizang Plateau, China. Novon 20: 172-174. http://dx.doi.org/10.3417/2003045

Martins, L. 2006. Klaseopsis and Archiserratula - two new genera segregated from Serratula (Compositae, Cardueae). Taxon 55: 973-976. http://dx.doi.org/10.2307/25065691

McNeill, J., Barrie, F.R., Buck, W.R., Demoulin, V., Greuter, W., Hawksworth, D.L., Herendeen, P.S., Knapp, S., Marhold, K., Prado, J., Prud'homme van Reine, W.F., Smith, G.F., Wiersema, J.H. \& Turland, N.J. (eds.) 2012. International Code of Nomenclature for algae, fungi, and plants (Melbourne Code): Adopted by the Eighteenth International Botanical Congress Melbourne, Australia, July 2011. Regnum Vegetabile 154. Königstein: Koeltz Scientific Books.

Raab-Straube, E. von 2003. Phylogenetic relationships in Saussurea (Compositae, Cardueae) sensu lato, inferred from morphological, ITS and trnL-trnF sequence data with a synopsis of Himalaiella gen. nov., Lipschitziella and Frolovia. Willdenowia 33: 379-402.

Raab-Straube, E. von 2009. Saussurea luae (Compositae, Cardueae), a new species of snow lotus from China. Willdenowia 39: 101-106. http://dx.doi.org/10.3372/wi.39.39112

Raab-Straube, E. von 2011. The genus Saussurea (Compositae, Cardueae) in China: Taxonomic and nomenclatural notes. Willdenowia 41: 83-95. http://dx.doi.org/10.3372/wi.41.41109

Ronquist, F. \& Huelsenbeck, J.P. 2001. MrBayes: Bayesian inference of phylogeny. Bioinformatics 17: 754-755. http://dx.doi.org/10.1093/bioinformatics/17.8.754

Saklani, A. \& Rao, R.R. 2000. Saussurea DC. Pp. 13-28 in: Pangtey, Y.P.S. \& Rawat, R.S. (eds.), High altitudes of the Himalaya: Biogeography, ecology, and conservation. Nainital: Gyanodaya Prakashan.

Sánchez-Jiménez, I., Lazkov, G.A., Hidalgo, O. \& Garnatje, T. 2010. Molecular systematics of Echinops L. (Asteraceae, Cynareae): A phylogeny based on ITS and trnL-trnF sequences with emphasis on sectional delimitation. Taxon 59: 698-708.

Schultz, C.H. 1846. Bemerkungen zu der Tribus der Cynareen Less. Linnaea 19: 321-336.

Shi, Z. \& Jin, S.Y. 1999. Saussurea DC. Pp. 1-243 in: Chen, Y.L. \& Shi, Z. (eds.), Flora Republicae Popularis Sinicae, vol. 78(2). Beijing: Science Press.

Shi, Z. \& Raab-Straube, E. von 2011. Saussurea group. Pp. 42-149 in: Wu, Z.Y., Raven, P.H. \& Hong, D.Y. (eds.), Flora of China, vol. 20-21, Asteraceae. Beijing: Science Press; St. Louis: Missouri Botanical Garden Press.

Susanna, A. \& Garcia-Jacas, N. 2007. Tribe Cardueae. Pp. 123-146 in: Kadereit, J.W. \& Jeffrey, C. (eds.), The families and genera of vascular plants, vol. 8, Flowering plants: Eudicots; Asterales. Berlin, Heidelberg: Springer.

Susanna, A. \& Garcia-Jacas, N. 2009. Cardueae (Carduoideae). Pp. 293-313 in: Funk, V.A., Susanna, A., Stuessy, T.F. \& Bayer, R.J. (eds.), Systematics, evolution, and biogeography of Compositae. Vienna: International Association for Plant Taxonomy.

Susanna, A., Garcia-Jacas, N., Hidalgo, O., Vilatersana, R. \& Garnatje, T. 2006. The Cardueae (Compositae) revisited: Insights from ITS, $\operatorname{trnL}$-trnF, and matK nuclear and chloroplast DNA analysis. Ann. Missouri Bot. Gard. 93: 150-171. 
Susanna, A., Galbany-Casals, M., Romaschenko, K., Barres, L., Martín, J. \& Garcia-Jacas, N. 2011. Lessons from Plectocephalus (Compositae, Cardueae-Centaureinae): ITS disorientation in annuals and Beringian dispersal as revealed by molecular analyses. Ann. Bot. (Oxford) 108: 263-277.

http://dx.doi.org/10.1093/aob/mcr138 http://dx.doi.org/10.3417/0026-6493(2006)93[150:TCCRIF]2.0 $\mathrm{CO} ; 2$

Swofford, D.L. 2003. PAUP*: Phylogenetic analysis using parsimony (*and other methods), version 4.0b10. Sunderland, Massachusetts: Sinauer.

Tamura, K., Dudley, J., Nei, M. \& Kumar, S. 2007. MEGA4: Molecular Evolutionary Genetics Analysis (MEGA) software version 4.0. Molec. Biol. Evol. 24: 1596-1599.

http://dx.doi.org/10.1093/molbev/msm092

Vilatersana,R.,Garcia-Jacas,N.,Garnatje,T.,Molero,J.,Sonnante,G. \& Susanna, A. 2010. Molecular phylogeny of the genus Ptilostemon (Compositae: Cardueae) and its relationships with Cynara and Lamyropsis. Syst. Bot. 35: 907-917.

http://dx.doi.org/10.1600/036364410X539952
Wang, Y.J., Pan, J.T., Liu, S.W. \& Liu, J.Q. 2005. A new species of Saussurea (Asteraceae) from Tibet in west China and its systematic position evidenced by ITS sequences. Bot. J. Linn. Soc. 147: 349-356. http://dx.doi.org/10.1111/j.1095-8339.2005.00350.x

Wang, Y.J., Liu, J.Q. \& Miehe, G. 2007. Phylogenetic origins of the Himalayan endemic Dolomiaea, Diplazoptilon and Xanthopappus (Asteraceae: Cardueae) based on three DNA fragments. Ann. Bot. (Oxford) 99: 311-322. http://dx.doi.org/10.1093/aob/mcl259

Wang, Y.J., Susanna, A., Raab-Straube., E. von, Milne, R. \& Liu, J.Q. 2009. Island-like radiation of Saussurea (Asteraceae: Cardueae) triggered by uplifts of the Qinghai-Tibetan Plateau. Biol. J. Linn. Soc. 97: 893-903. http://dx.doi.org/10.1111/j.1095-8312.2009.01225.x

Zhang, X.L., Wang, Y.J., Ge, X.J., Yuan, Y.M. \& Liu, J.Q. 2009. Molecular phylogeny and biogeography of Gentiana sect. Cruciata (Gentianaceae) based on four chloroplast DNA data sets. Taxon 58: $862-870$.

Appendix 1. List of taxa, geographic origin, voucher and GenBank accession numbers (ITS, $\operatorname{trn} L-F, m a t K, n d h F, r b c L$ ). Detailed location is only given for newly extracted material. GenBank accession numbers marked with superindex were already published ( ${ }^{1}$ Susanna $\&$ al., $2006 ;{ }^{2}$ Susanna $\&$ al., $2011 ;{ }^{3}$ Anderberg \& al., 2007; ${ }^{4}$ Sánchez-Jiménez \& al., 2010; ${ }^{5}$ Hidalgo \& al., 2006; ${ }^{6}$ Vilatersana \& al., 2010; ${ }^{7}$ Barres \& al., 2013$)$.

Alfredia cernua (L.) Cass.; Denmark, Copenhagen Botanical Garden (BC); AY826225'; AY772269'; AY013519'; KC5899127; KC5897857 . Alfredia nivea Kar.

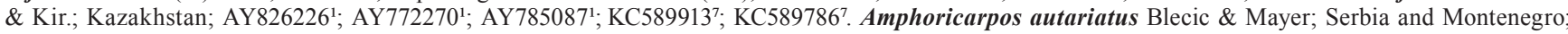

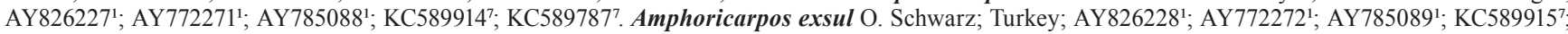

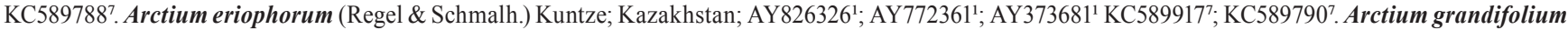
(Kult.) S. López, Romaschenko, Susanna \& N. Garcia; Kazakhstan; AY826268'; AY772310'; AY373679'; KC5899187; KC5897917. Arctium lappaceum (Schrenk)

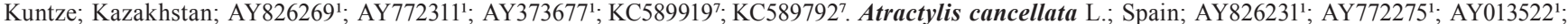
KC5899247; KC5897977. Atractylis carduus (Forssk.) Christ.; Egypt; AY826232'; AY772276'; AY013523; KC5899257; KC5897987. Atractylodes japonica

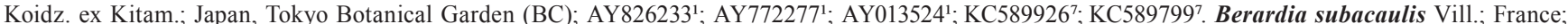

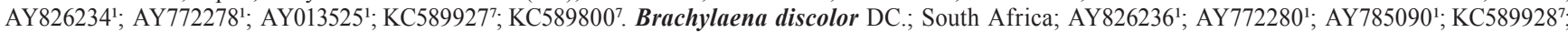
KC5898017. Callicephalus nitens (M. Bieb. ex Willd.) C.A. Mey.; Armenia; AY826237'; AY772281'; AY013492'; JF754837; KC5898027. Cardopatium corymbosum (L.) Pers.; Greece; AY826238'; AY772282'; AY0135261; KC5899297\% KC5898037 . Carduncellus duvauxii Batt. \& Trab.; Morocco; AY8262391; AY7722831;

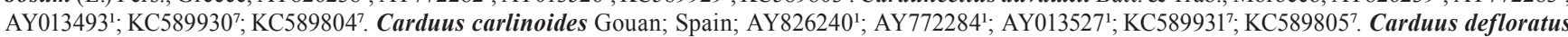

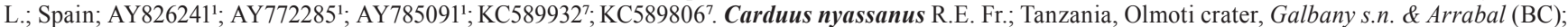

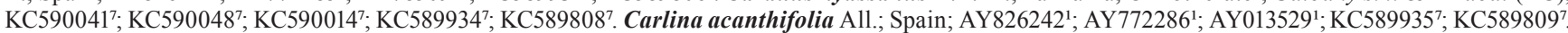
Carlina falcata Svent.; Spain; AY826243; AY772287'; AY013530'; KC5899367; KC5898107. Carthamus oxyacantha M. Bieb.; Iran; AY826248'; AY772292'; AY013494'; KC5899407; KC5898147. Carthamus turkestanicus Popov.; Armenia, AY8262491; AY772293'; AY785093'; KC5899417; KC5898157. Centaurea

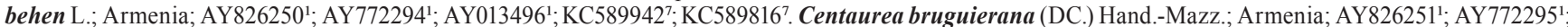

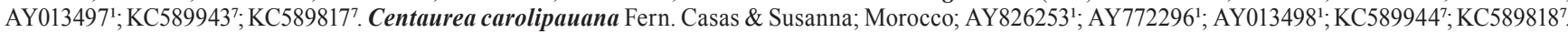

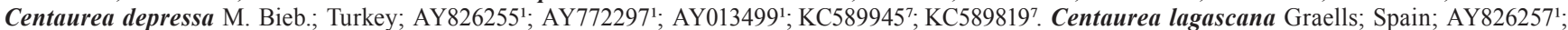

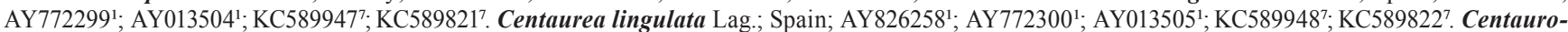
dendron palmiforme Skottsb.; Chile; JF7548062; JF7547572; KC5900157\% JF754836 ${ }^{2}$; KC5898237. Centaurothamnus maximus Wagenitz \& Dittrich; Yemen;

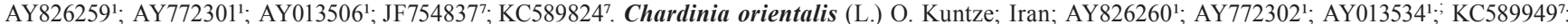
KC5898257. Cheirolophus mauritanicus (Font Quer) Susanna; Morocco; AY826261'; AY772303'; AY013507' JF7548387; KC5898267. Cheirolophus teydis (C. Smith) G. López; Spain; AY826262'; AY772304'; AY785094'; JF754839; KC5898277. Cirsium echinus (M. Bieb.) Hand.-Mazz.; Iran; AY826263'; AY7723051; AY013535'; KC5899507; KC5898287. Cirsium nipponicum Makino; Japan, Tokyo Metropolitan Medicinal Plant Garden (BC); KC5900427; KC5900497; KC5900167; KC5899517; KC5898297. Cirsium ochrolepidium Juz.; Uzbekistan; AY8262641; AY772306 ${ }^{1}$; AY785095'; KC5899527; KC5898307 . Cirsium palustre (L.) Scop.; Spain; AY826265'; AY772307'; AY013536 ${ }^{1}$; KC5899537; KC5898317. Cousinia coronata Franch.; Uzbekistan; AY826267'; AY7723091'; AY373662';

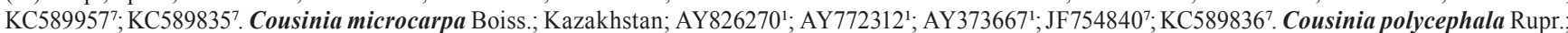

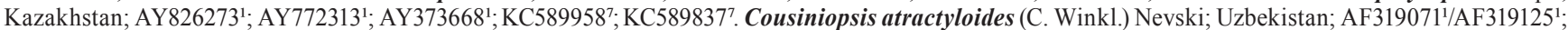

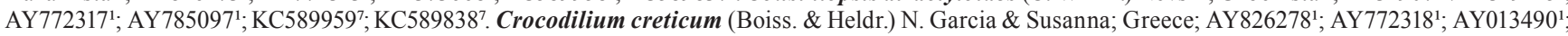
KC5899607; KC5898397. Crocodilium syriacum Cass.; Egypt; AY826279¹; AY772319'; AY7850981' KC5899617; KC5898407. Cynara cornigera Lind.; Egypt;

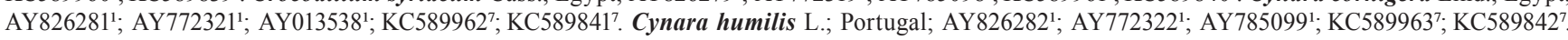
Dipterocome pusilla Fisch. \& C.A. Mey.; Voucher 1: Iran, FJ813487³; -; -; FJ8134883; -. Voucher 2: Iran, Joharcchi \& Zangoori 19925 (S); -; KC5900537; KC5900207; -; KC5898437. Dolomiaea souliei (Franch.) C. Shih; China, Sichuan, Daocheng, WYJ20090914 (LZU); JQ303104; JQ303108; JQ303113; -; -.

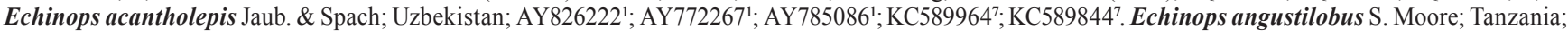
GU1165054; GU1345314; KC5900217; KC5899657\% KC5898457. Echinops hoehnelii Schweinf.; Kenya; GU1165064; GU1345654; KC5900227; KC5899667;

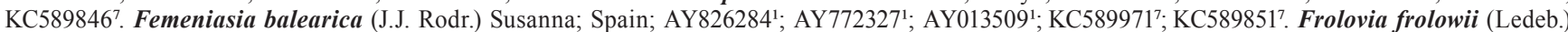
Raab-Straube; China, Xinjiang, Altai, Liu 200014 (LZU); AY914822; AY914862; JQ303114; -; -. Galactites tomentosa Moench; Spain; AY826285'; AY7723281. AY013541'; KC58997277 KC5898527. Goniocaulon indicum C.B. Clarke; Ethiopia, Friis s.n. \& al. (K); JF7753937; JF7753857; KC5900237; JF7753977; KC5898537.

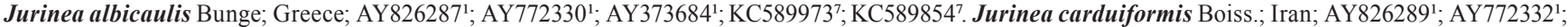
AY785103'; KC5899747; KC5898557. Jurinea humilis DC.; Spain; L35868'; KC5900547; KC5900247; KC5899757; KC5898567. Jurinea robusta Schrenk;

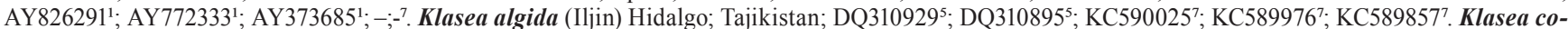
riacea (Fisch. \& C.A. Mey. ex DC.) Holub; Armenia; DQ3109265; DQ3108925; KC5900267; JF7548437; KC5898587. Lamyropappus schacaptaricus (B. Fedtsch.) Knorr. \& Tamamsch.; Kyrgyzistan; AY826296'; AY772335'; AY785104'; KC5899777 KC5898607. Lamyropsis carpini Greuter; Greece; GU9077246; KC590055;

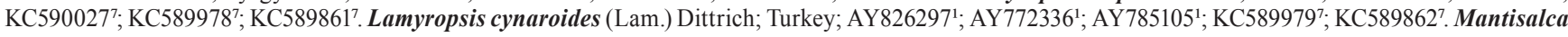


Appendix 1. Continued.

salmantica (L.) Briq. \& Cavill.; Spain; AY012292¹/AY0123281; JF754765²; KC5900287; JF754846²; KC5898637 Myopordon aucheri Boiss.; Iran; AY8262991; AY772338'; KC5900297; JF754847³ KC589864․ Myopordon hyrcanum (Bornm.) Wagenitz; Iran; AY826300'; AY7723391'; -; KC5899807; KC5898657. Notobasis syriaca (L.) Cass.; Egypt; AY826302'; AY772340'; AY013545'; KC5899817; KC5898667. Ochrocephala imatongensis (Philipson) Dittrich; Ethiopia;

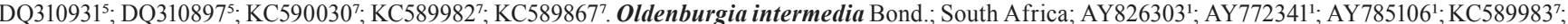
KC5898687. Olgaea baldshuanica (C. Wink1.) Iljin; Tadjikistan; AY826304; AY772342'; AY7851071; KC5899847; KC5898697. Olgaea pectinata Iljin; Kazakhstan; AY826305'; AY772343'1; AY785108'; KC5899857; KC5898707. Onopordum nervosum Boiss.; France, Dijon Botanical Garden (BC); AY8263081; AY772346'; AY785109'; KC5899867; KC5898717. Onopordum tauricum Willd.; Germany, Berlin Botanical Garden (BC); AY826309'; AY772347'; AY785110';

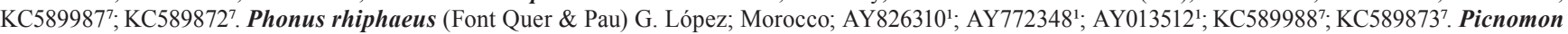
acarna (L.) Cass.; Iran; AY826311'; AY772349'; AY013549'; KC5899897; KC5898747. Plectocephalus americanus D. Don; USA; JF7548172; JF754769²; KC5900317; JF7548532; KC5898757. Plectocephalus tweediei (Hook. \& Arn.) N. Garcia \& Susanna; Argentina; JF775392²; JF775384²; KC5900337; JF7753962;

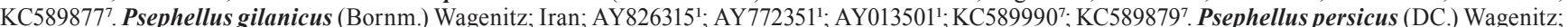
Iran; AY826316 ${ }^{1}$; AY772352'; AY013500'; JF75485²; KC5898807. Ptilostemon abylensis (Maire) Greuter; Morocco; GU9077266; KC5900567; KC5900357; KC5899917; KC5898827. Ptilostemon afer (Jacq.) Greuter; Germany, Freiburg Botanical Garden (BC); AY826318'; AY772354'; AY785111'; KC5899927;

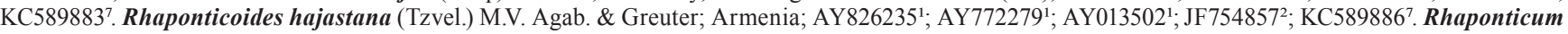

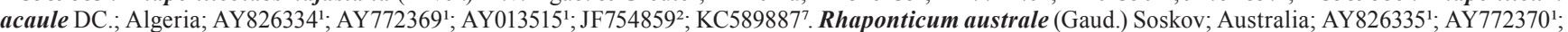

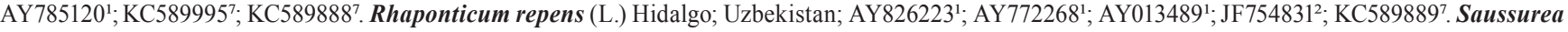

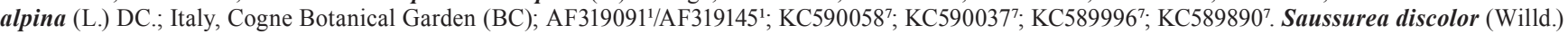
DC.; Switzerland, Meyrin Botanical Garden (BC); AF3190921/AF3191461'; KC5900597; KC5900387; KC5899977\% KC5898917. Saussurea gnaphalodes (Royle) Sch. Bip.; China, Qinghai, Chenduo, J.Q. Liu 839 (LZU); AY366324; AY328106; AB118147; -; -. Saussurea involucrata (Kar. \& Kir.) Sch. Bip.; China, Xinjiang (LZU); AY366335; AY328115; AB118148; -; -. Saussurea leontodontoides (DC.) Sch. Bip.; China, Qinghai, Maqing, C.Q. Ao 49 (LZU); JQ303105; JQ303105; JQ303115; -; -. Schischkinia albispina (Bunge) Iljin; Turkmenistan; AY826325'; AY772360'; AY785113'; JF754862²; KC5898927. Serratula coronata L.; Austria, Vienna Botanical Garden (BC); AY826327'; AY772362'; AY785114'; JF754863²; KC5898937. Shangwua denticulata (DC.) Raab-Straube \& Yu J. Wang; China, Xizang, Nielamu, J.Q. Liu 07150 (LZU); JQ303106; JQ303110; JQ303116; JQ303118; JQ303120. Shangwua jacea (DC.) Yu J. Wang \& Raab-Straube;

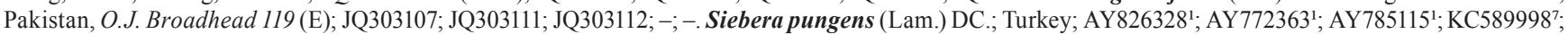
KC5898947. Silybum marianum (L.) Gaertner; Spain; AY826329'; AY7723641; AY013551'; KC5899997; KC5898957. Staehelina dubia L.; France; AY826330'; AY772365'; AY785116'; KC5900007; KC5898967 . Staehelina fruticosa L.; Greece; AY826331'; AY772366'; AY785117'; KC5900017; KC5898977. Staehelina lobelii DC.; Turkey; AY826332'; AY772367'; AY785118'; KC5900027; KC5898987. Stizolophus balsamita (Lam.) Cass. ex Takht.; Armenia; AY826336'; AY772371'; AY785121'; JF7548647; KC5898997. Stizolophus coronopifolius Cass.; Turkey; AY826337'; AY772372'; AY013516'; JF7548657; KC5899007. Synurus palmatopinnatifidus (Makino) Kitam.; Japan, the Nippon Shinyaku Institute for Botanical Research (BC); AY826338'; AY772373'; AY013552'; KC5900037; KC5899017. Syreitschikovia spinulosa (Franch.) Pavlov; Kazakhstan; AY826339'; AY772374'; AY7851221' KC5900047; KC5899027. Tarchonanthus cam-

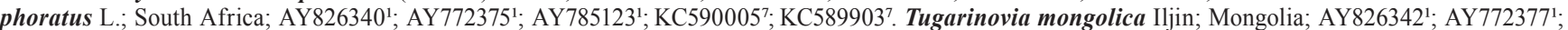
AY785124'; KC5900067; KC5899047. Tyrimnus leucographus (L.) Cass.; Spain; AY826343'; AY772378'; AY013554'; KC5900077; KC5899057. Volutaria crupinoides (Desf.) Maire; Morocco; AY826344'; AY772379'; AY7851251'; JF754867²; KC5899067. Xanthopappus subacaulis C. Wink1.; China, Qinghai, Liu

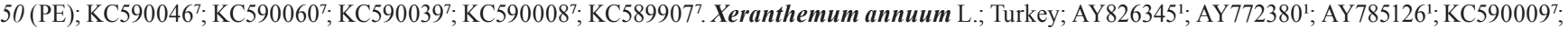
KC5899087. Xeranthemum inapertum (L.) Miller; Spain; AY826347; AY772381'; AY013555'; KC5900107; KC5899097. Xeranthemum longepapposum Fisch.

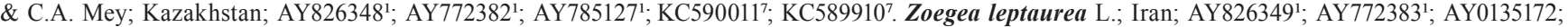
JF7548687; KC5899117.

Appendix 2. Voucher specimens of taxa used for morphological examinations in this study.

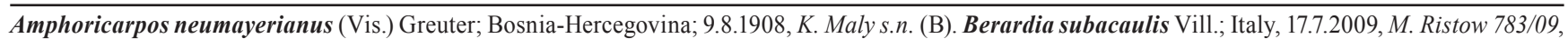
D. Lauterbach \& B. Gemeinholzer (B100355114). Chardinia orientalis (L.) Kuntze; Uzbekistan, 21.5.1998, Häffner s.n. (B). Saussurea leontodontoides (DC.) Sch. Bip.; China, Qinghai, Maqing, C.Q. Ao 49 (LZU). Shangwua denticulata (DC.) Raab-Straube \& Yu J. Wang; Nepal, 1929, L. Dhevoj 256 (E00451529); China, Xizang, Nielamu, J.Q. Liu 07150 (LZU); China, Xizang, Jilong, J.Q. Liu Liujq-09xz-lzt-073 (LZU). Shangwua jacea (Klotzsch) Yu J. Wang \& RaabStraube; Pakistan, O.J. Broadhead 119 (E); India, Ladak, 17.8.1931, W. Koelz 2617 (L0833898). Siebera pungens (Lam.) J. Gay; Turkey, 24.8.1999, F. Schuhwerk 99/299 (B100021017). Staehelina dubia L.; Spain, 2.7.1995, B. Catón \& P.M. Uribe-Echebarría IAN 790 (B); Xeranthemum annuum L.; Greece, 13.7.1998, R. Eisenblätter \& E. Willing 66918 (B). 